\title{
Demonstration of bidirectional photoinduced electron transfer (PET) sensing in 4-amino-1,8-naphthalimide based thiourea anion sensors $\dagger$
}

\author{
Emma B. Veale, ${ }^{a}$ Gillian M. Tocci, ${ }^{a}$ Frederick M. Pfeffer, ${ }^{b}$ Paul E. Kruger ${ }^{a, c}$ and Thorfinnur Gunnlaugsson $* a$ \\ Received 7th April 2009, Accepted 26th May 2009 \\ First published as an Advance Article on the web 6th July 2009 \\ DOI: $10.1039 / \mathrm{b} 907037 \mathrm{k}$
}

The thiourea based 4-amino-1,8-naphthalimide molecules 1-5 were designed as fluorescent anion sensors and their photophysical properties investigated upon recognition of biologically relevant anions such as acetate, dihydrogen phosphate and fluoride in DMSO. Synthesised in a single step from their respective aniline precursors, 6-9, these molecules were designed on the fluorophore-spacer-receptor principle, where in the case of sensors 1-3 the thiourea anion recognition moieties were connected to the fluorophore via the 4-amino moiety, while sensors $\mathbf{4}$ and $\mathbf{5}$ had the thiourea moieties connected to the 'imide' via a $\mathrm{CH}_{2}$ spacer. The current study showed that 1-5 operated as photoinduced electron transfer (PET) sensors, as no significant changes were observed in their absorption spectra, while their fluorescence emissions were quenched upon recognition of ions such as $\mathrm{AcO}^{-}, \mathrm{H}_{2} \mathrm{PO}_{4}^{-}$and $\mathrm{F}^{-}$, which demonstrates that bidirectional PET sensing occurs in such naphthalimide based anion sensors.

\section{Introduction}

The detection and real-time monitoring of ions and molecules is a rapidly developing field within supramolecular chemistry. ${ }^{1}$ In particular, the development of responsive luminescent ${ }^{2}$ and colorimetic $^{3}$ sensors for the detection of anions has emerged as a highly topical area of research in the past a few years ${ }^{4}$ where the use of charge neutral anion receptors, such as amides, ureas and thioureas in such sensing has been widely established. ${ }^{5-8} \mathrm{We}$ previously demonstrated the first examples of the use of the photoinduced electron transfer (PET) principle for the sensing of anions using charge neutral anion receptors. ${ }^{9}$ These sensors comprised of a fluorophore-spacer-receptor model, ${ }^{10,11}$ where the fluorescence emission was quenched upon anion recognition, due to enhanced PET from the anion complexed receptor to the excited state of the fluorophore. ${ }^{12}$ The use of 4-amino-1,8-naphthalimide based fluorophores, which possess Internal Charge Transfer (ICT) excited states, in PET sensing has been demonstrated by several researchers, where the receptor sites are positioned at the 4-amino moiety of the aryl ring. ${ }^{13-15}$ The "push-pull" nature of the ICT excited state in the 4-amino-1,8-naphthalimide structure favours PET quenching of the excited state by electron rich receptors positioned at the 4-position, more so than from the imide site. This was first demonstrated in the work of de Silva and Rice, ${ }^{16}$ and Marcus and $\mathrm{GaO}^{17}$ who described this selective quenching as directional PET quenching. This phenomenon has been used as a model for the photosynthetic reaction centre ${ }^{16}$ and has also

${ }^{a}$ School of Chemistry, Centre of Synthesis and Chemical Biology, University of Dublin, Trinity College Dublin, Dublin2, Ireland. E-mail: gunnlaut@tcd.ie; Tel: + 35318963459

${ }^{b}$ School of Life and Environmental Sciences, Faculty of Science and Technology, Deakin University, Waurn Ponds, 3217, Australia

'Department of Chemistry, College of Science, University of Canterbury, Christchurch, 8020, New Zealand

$\dagger$ Electronic supplementary information (ESI) available: Figures ESI 1-8. See DOI: $10.1039 / \mathrm{b} 907037 \mathrm{k}$ been employed by Qian et al., ${ }^{18}$ and Tian et al., ${ }^{19}$ in the sensing of cations.

We have extensively used the naphthalimide fluorophore in our research endeavours, such as for the sensing of $\mathrm{pH}$ in hydrogels, ${ }^{20}$ for the sensing and biological imaging of $\mathrm{Zn}(\mathrm{II}),{ }^{21}$ in the colorimetric sensing of anions ${ }^{22,23}$ and for targeting DNA using $\mathrm{Ru}(\mathrm{II})$ based conjugates. ${ }^{24}$ In this full article, we show that fluorescent anion sensing can also be achieved, either by positioning the anion recognition moiety, a diaryl thiourea moiety, at the 4-amino moiety, e.g. $1-3,{ }^{25}$ or at the imide site, e.g. 4 and 5 (Fig. 1). ${ }^{26}$ Both types of sensors gave rise to PET quenching upon anion recognition in DMSO, which demonstrates that bidirectional PET anion sensing is clearly possible for such structural isomers (i.e. PET occurs from the receptor site to the fluorophore independent of its location). In contrast, the aniline precursors 6 and 9, did not uphold such bidirectional PET quenching, as only the emission of $\mathbf{6}$ was significantly quenched in alkaline solution upon carrying out a $\mathrm{pH}$ titration of these sensors.

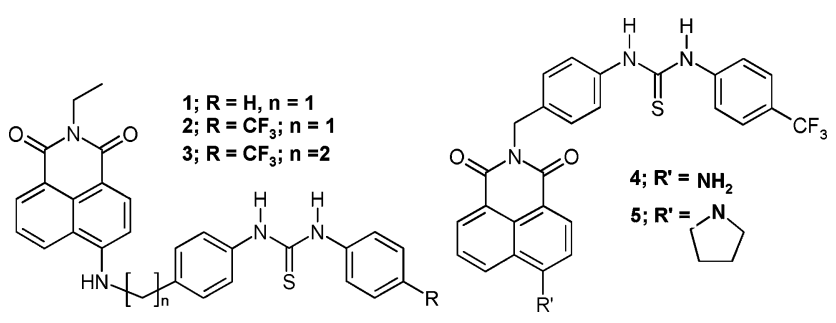

Fig. 1 Structures of the naphthalimide anion sensors 1-5.

\section{Results and discussion}

Design and synthesis

The synthesis of the sensors $\mathbf{1 - 5}$ is shown in Scheme 1, starting from their aniline precursors 6-9. The precursor to both $\mathbf{1}$ and $\mathbf{2}$ was $\mathbf{6}$, while $\mathbf{7}$ was used for the formation of $\mathbf{3}$, which was 

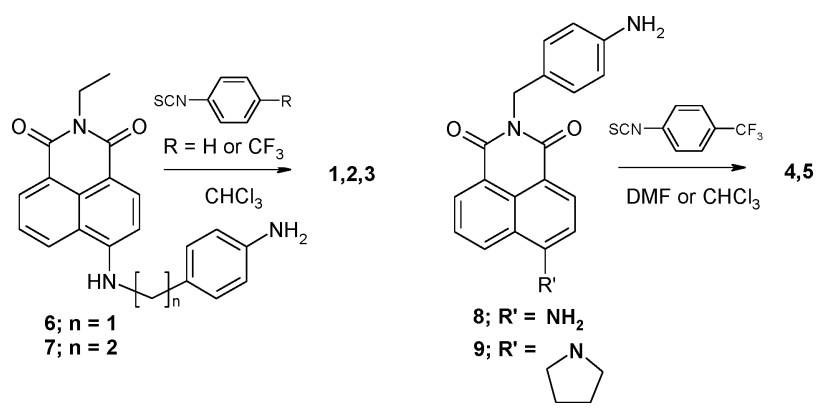

Scheme 1 Synthesis of PET sensors 1-5, from the aniline derivatives 6-9.

also made to investigate the effect of having an ethylene spacer, as these two carbon spacers have been shown to give better photostability for naphthalimide sensors. We have previously used these starting materials in the synthesis of $\mathrm{Zn}(\mathrm{II})$ sensors. ${ }^{21}$ The synthesis of $\mathbf{1}$ and $\mathbf{2}$ was achieved by reacting $\mathbf{6}$ with phenylor 4-(trifluoromethyl)phenyl isothiocyanate, respectively, at room temperature in dry $\mathrm{CHCl}_{3}$, yielding $\mathbf{1}$ and $\mathbf{2}$ in $49 \%$ and $58 \%$ yield, respectively. ${ }^{25}$ Similarly, sensor 3 was formed by treating 7 with 4-(trifluoromethyl)phenyl isothiocyanate in 60\% yield after aqueous work-up and purification by flash chromatography (See Experimental).

The synthesis of sensors $\mathbf{4}$ and $\mathbf{5}$ has previously been described by us. $^{26}$ In short, the precursor $\mathbf{8}$, which yielded $\mathbf{4}$, was formed by first reacting 4-aminobenzyl amine with 4-nitro-1,8-naphthalic anhydride in $\mathrm{EtOH}$ followed by catalytic hydrogenation in the presence of $10 \% \mathrm{Pd} / \mathrm{C}$ catalyst and 3 atm. $\mathrm{H}_{2}$. Similarly, 9, was made from 4-chloro-1,8-naphthalic anhydride followed by nucleophilic aromatic substitution using neat pyrrolidine under reflux for 18 hours. The two sensors with the receptor at the "imide" site were prepared by treating the intermediates 8 and 9 with 4-(trifluoromethyl)phenyl isothiocyanate in DMF or $\mathrm{CHCl}_{3}$ to give $\mathbf{4}$ and $\mathbf{5}$ in $78 \%$ and $72 \%$ yields, respectively.

The ${ }^{1} \mathrm{H}$ NMR spectra of all five sensors (400 MHz, DMSO- $d_{6}$, see ESI for 1 and 4, respectively $\dagger$ ) showed characteristic resonances for the $\mathrm{N}-\mathrm{H}$ protons of the thiourea moieties and for the $\mathrm{N}-\mathrm{H}$ proton of the 4-amino moiety in the case of 1-4.

\section{Spectroscopic evaluation of 1-5 in DMSO}

The photophysical properties of sensors 1-5 and their ability to sense anions were evaluated using $\mathrm{UV} / \mathrm{V}$ is and fluorescence spectroscopy in DMSO. The absorption spectra of all sensors showed the presence of the ICT band of the naphthalimide, arising due to the push-pull nature of the donating amine and the withdrawing diimide, with $\lambda_{\max }$ at $c a .444 \mathrm{~nm}(\log \varepsilon \sim 4.20)$ for 1-3, and $\lambda_{\max }$ appearing at $438 \mathrm{~nm}(\log \varepsilon=5.19)$ and $454 \mathrm{~nm}(\log$ $\varepsilon=5.30$ ), for $\mathbf{4}$ and $\mathbf{5}$, respectively, Table 1 .

Table 1 Photophysical properties of 1-5 measured in DMSO

\begin{tabular}{lllll}
\hline Sensor & $\lambda_{\text {abs }}(\mathrm{nm})$ & $\log \varepsilon$ & $\lambda_{\text {em }}(\mathrm{nm})$ & $\Phi_{\mathrm{F}}$ \\
\hline $\mathbf{1}$ & 444 & 4.2 & 527 & 0.60 \\
$\mathbf{2}$ & 443 & 4.2 & 527 & 0.71 \\
$\mathbf{3}$ & 443 & 4.3 & 526 & - \\
$\mathbf{4}$ & 438 & 5.2 & 528 & 0.41 \\
$\mathbf{5}$ & 454 & 15.3 & 533 & 0.01 \\
\hline
\end{tabular}

Excitation of the ICT absorption band of these sensors gave rise to long wavelength emission bands centred at $c a .527 \mathrm{~nm}$ for 1-4 and $533 \mathrm{~nm}$ for $\mathbf{5}$. The fluorescence quantum yields $\left(\Phi_{\mathrm{F}}\right)$ of 1, 2, 4 and 5 were also determined and are listed in Table 1, and demonstrate that $\mathbf{1}$ and $\mathbf{2}$ were more emissive than $\mathbf{4}$ or $\mathbf{5}$. It is worth noting the difference in $\Phi_{\mathrm{F}}$ values for the structural isomers $\mathbf{2}$ and $\mathbf{4}$, which seems to indicate that the position of the receptor moiety is important to the photophysical properties of these systems. This is not unexpected, and demonstrates that the excited state of $\mathbf{4}$ is possibly quenched more readily via the PET mechanism. This would also suggest that bi-directional electron transfer should be possible in sensor $\mathbf{4}$. The significantly reduced $\Phi_{\mathrm{F}}$ for $\mathbf{5}$ in comparison to the rest of these systems, is attributed to its excited state being affected by its bulkier 4-amino tertiary amine, which partially 'twists' the amino group out of the plane of the naphthalimide ring.

\section{Ground state evaluation of 1-5 in the presence of various anions in DMSO}

Having evaluated the basic spectroscopic properties of 1-5 in DMSO, we next evaluated their ability to sense anions (as their tetrabutylammonium (TBA) salts) in this competitive solvent.

In most "ideal" PET systems, ${ }^{27}$ a quenching of fluorescence is accompanied by no, or only minor changes in the absorption spectra of the sensors. This is due to the presence of the covalent spacer which prevents any ground state $n-\pi$ or $\pi-\pi^{*}$ interactions. This is demonstrated in Fig. 2, for 4, which has the anion receptor at the imide site upon titration with $\mathrm{AcO}^{-}$. Similarly, no significant changes were observed in the structure of the ICT band upon titration with other anions such as $\mathrm{H}_{2} \mathrm{PO}_{4}{ }^{-},{ }^{26} \mathrm{Cl}^{-}$or $\mathrm{Br}^{-}$for either 4 or 5. However, it is also clear from Fig. 2, that measurable changes were observed at lower wavelengths between $c a$. 320$370 \mathrm{~nm}$, assigned to the anion binding at the receptor site (see also Fig. 2, inset).

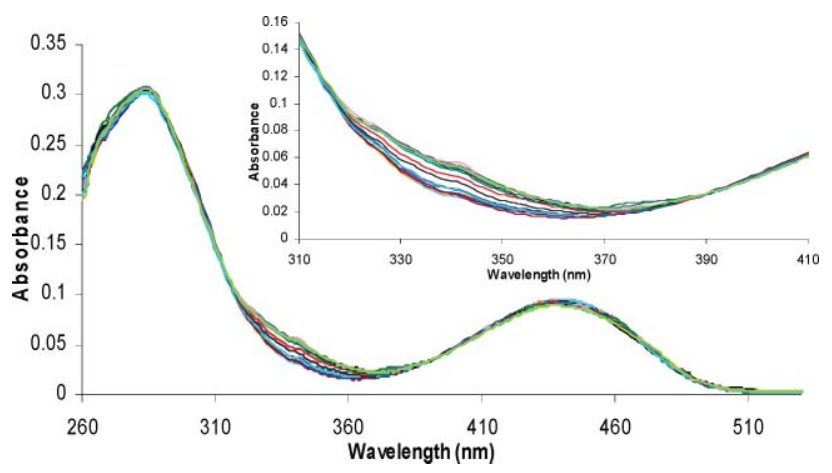

Fig. 2 Absorbance spectrum of $\mathbf{4}$ in DMSO upon the addition of $\mathrm{AcO}^{-}$ $(0 \rightarrow 95 \mathrm{mM})$, showing the overall changes. Inset: the changes observed for the binding of the anion at the receptor moiety.

However, it is worth noting, that some changes were observed in the ICT band of 1-3 upon titration with these anions, as shown for $\mathbf{1}$ in Fig. 3. This is due to the fact that the ICT gives rise to a $\delta^{+}$on the 4-amino moiety, which through electrostatic interactions 'experiences' the presence of the complexed anion, shifting the spectra to the red with the formation of an isosbestic point at $383 \mathrm{~nm}$. Similar changes, where the fluorescence emission 


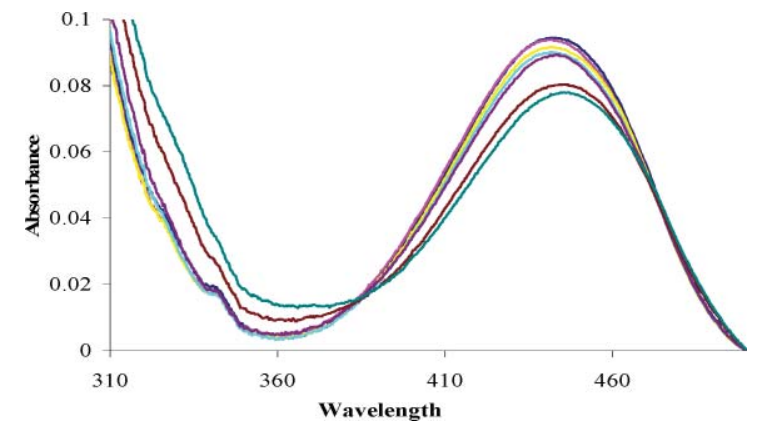

Fig. 3 Absorbance spectrum of 1 in DMSO showing the changes in the ICT band upon addition of $\mathrm{AcO}^{-}(0 \rightarrow 55 \mathrm{mM})$.

is shifted to the blue, have been seen for naphthalimide based cation sensors. ${ }^{20,21}$

There were also no significant changes in the absorbance spectra of 1-3 up to the addition of about ca. $30 \mathrm{mM}$ of $\mathrm{F}^{-}$, suggesting that to this point a PET process was taking place. However, upon further addition of $\mathrm{F}^{-}$, a dramatic red shift was observed with the formation of two clear isosbestic points in the absorption spectra of 1-3. These changes were clearly visible to the nakedeye, by the fluorescent green colour of the solution changing to a deep purple colour. Similarly, the colorimetric detection of $\mathrm{F}^{-}$ was also achieved by $\mathbf{4}$, but at a much lower concentration, $c a$. $0.2 \mathrm{mM}$. These colour changes are due to deprotonation of the more acidic 4-amino naphthalimide moiety of these sensors as previously demonstrated by us and several other researchers. ${ }^{28}$ This was confirmed by carrying out such titrations on $\mathbf{5}$, which lacks the $\mathrm{N}-\mathrm{H}$ protons, as no such long wavelength shift was observed upon titration with $\mathrm{F}^{-}$(See ESI $\dagger$ ). However, in the case of $\mathbf{5}$, we propose that deprotonation can occur at the thiourea moiety instead, making the receptor highly electron rich, which should result in effective quenching of the naphthalimide emission by electron transfer from the receptor to the excited state of the naphthalimide unit.

\section{Excited state evaluation of 1-3 in the presence of various anions in DMSO}

In a similar way to that described above, we next carried out anion titrations against 1-5 by observing the changes in their fluorescence emission. In the case of $\mathbf{1 - 3}$, which have their receptor moiety functionalised at the 4-amino moiety, all gave rise to an enhancement in the PET process upon anion recognition. This resulted in quenching of their emission as demonstrated by the changes in sensor 1 upon titration with $\mathrm{H}_{2} \mathrm{PO}_{4}{ }^{-}$as shown in Fig. 4. These changes were accompanied by a corresponding decrease in quantum yield, Table 2. Such an effect is expected, whereby the electron transfer is allowed upon an increase in the reduction potential of the receptor following anion recognition. Moreover, due to the nature of the ICT character of the naphthalimide moiety, the electron transfer from the receptor that is connected to the 4-amino moiety (via a spacer) to the excited state of the fluorophore would be favoured for these structures. The addition of $\mathrm{Cl}^{-}$and $\mathrm{Br}^{-}$did not lead to any significant changes in the emission of 1-3, indicating that the sensing was not due to any heavy atom effect.
Table 2 Quantum yields of 1, 2, 4 and 5 in the presence of various anions. ${ }^{a}$

\begin{tabular}{llc}
\hline Sensor & Anion & $\Phi_{\mathrm{f}}$ \\
\hline $\mathbf{1}$ & $\mathrm{AcO}^{-}$ & 0.25 \\
& $\mathrm{H}_{2} \mathrm{PO}_{4}^{-}$ & 0.24 \\
$\mathrm{~F}^{-}$ & 0.03 \\
$\mathbf{2}$ & $\mathrm{AcO}^{-}$ & - \\
$\mathrm{H}_{2} \mathrm{PO}_{4}^{-}$ & 0.056 \\
& $\mathrm{~F}^{-}$ & 0.002 \\
$\mathbf{4}$ & $\mathrm{AcO}^{-}$ & 0.31 \\
& $\mathrm{H}_{2} \mathrm{PO}_{4}^{-}$ & 0.25 \\
& $\mathrm{~F}^{-}$ & 0.06 \\
& $\mathrm{AcO}_{-}$ & 0.01 \\
$\mathbf{5}$ & $\mathrm{H}_{2} \mathrm{PO}_{4}^{-}$ & 0.01 \\
& $\mathrm{~F}^{-}$ & 0.008
\end{tabular}

${ }^{a}$ Measured in DMSO using naphthalimide as reference.

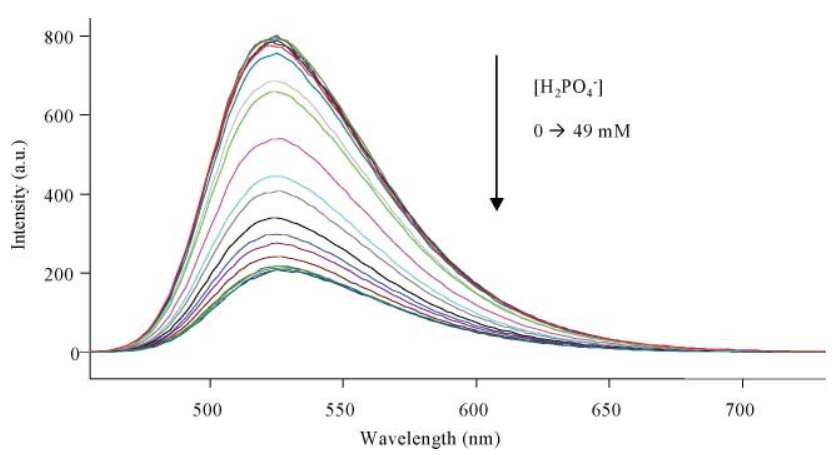

Fig. 4 Quenching of fluorescence of 1 upon addition of $\mathrm{H}_{2} \mathrm{PO}_{4}^{-}(0 \rightarrow$ $49 \mathrm{mM})$.

In a similar manner to that observed for $\mathrm{H}_{2} \mathrm{PO}_{4}^{-}, \mathrm{F}^{-}$caused an almost complete quenching in the fluorescence emission of 1-3 in DMSO, see Fig. 5A for 1. Moreover, as discussed above, at higher concentrations of $\mathrm{F}^{-}$, deprotonation of the 4-amino moieties occurred, which led to a red shift in the absorption spectra, with the formation of an isosbestic point. Excitation at this wavelength gave rise to the formation of long wavelength emission which increased in intensity as a function of increasing $\mathrm{F}^{-}$concentration, as demonstrated by the insert in Fig. 5B. Also shown in Fig. 5B are the changes occurring at $620 \mathrm{~nm}$ for the newly formed transition as a function of $-\log \left[\mathrm{F}^{-}\right]$.

While, interaction of $\mathbf{2}$ and $\mathbf{3}$ with $\mathrm{AcO}^{-}$also resulted in quenching of the fluorescence between $0 \rightarrow 0.2 \mathrm{mM}$ of $\mathrm{AcO}^{-}$, compound 1, did not give rise to such biphasic changes. Both sensors $\mathbf{2}$ and $\mathbf{3}$ exhibited initial quenching of their fluorescence emission followed by subsequent enhancement at higher concentrations of anion, $0.4 \mathrm{mM} \rightarrow 44 \mathrm{mM}$ (See ESI $\dagger$ ). We can attribute this to two binding processes, both of which occurred over approximately two log units as shown in Fig. 6. The first one of these involves the normal binding of the anion to the thiourea moiety, while the second process involves the 'binding', or interaction of the anion through electrostatic interactions, with the 4-amino group of the fluorophore, which is quite acidic (pseudo amide), due to the push-pull nature of the ICT state. Such secondary binding interactions have been demonstrated and exploited in anion sensing by Pfeffer et al. ${ }^{29}$ for structurally related systems. Furthermore, such secondary binding interactions are backed by the small changes seen in the absorption spectra at higher concentrations. It was also anticipated that both the 

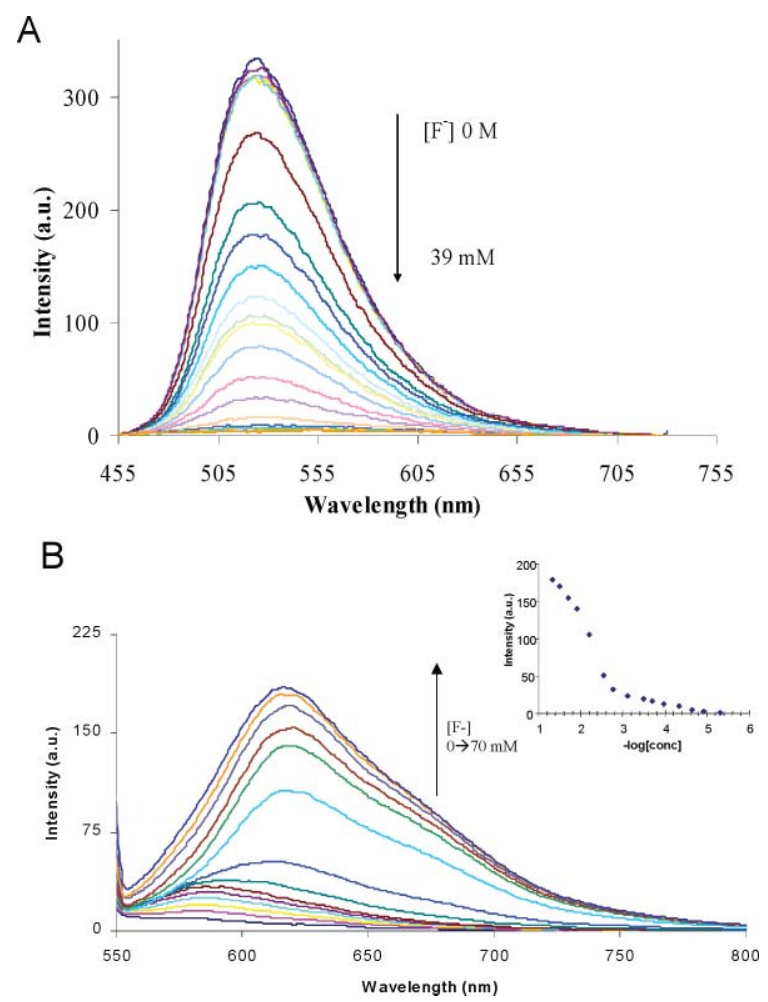

Fig. 5 (A) The changes in the fluorescence emission spectra of 1 upon titration with TBAF in DMSO upon excitation of the ICT band. (B) The changes observed at long wavelength of $\mathbf{1}$ upon deprotonation of the 4-amino moiety of the naphthalimide structure by $\mathrm{F}^{-}$. Inset: The changes observed at $620 \mathrm{~nm}$.

sensitivity of the anion recognition would differ according to the acidity of the thiourea protons and that the distance of the receptor from the fluorophore would have an effect on the magnitude of the quenching. This effect was investigated by carrying out titrations on 3, which showed that the naphthalimide emission was not quenched to the same degree as for $\mathbf{1}$. In all cases the addition of $\mathrm{MeOH}(\mathrm{ca} .10 \% \mathrm{v} / \mathrm{v})$ to a solution of sensor bound to anion resulted in a 're-switching on' of the emission, demonstrating that the process was fully reversible, i.e. the hydrogen bonding anion interactions were broken.

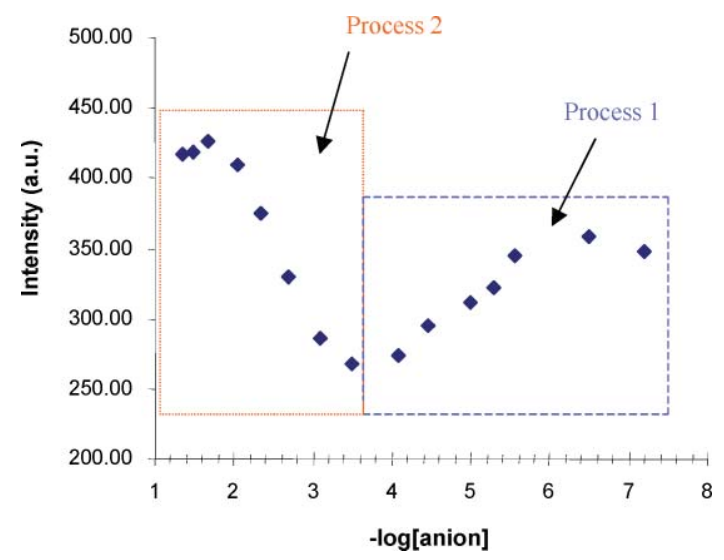

Fig. 6 Plot of intensity $v s .-\log \left[\mathrm{AcO}^{-}\right]$for titration of 2 with $\mathrm{AcO}^{-}$.
The degree of fluorescence quenching observed upon anion recognition also differed for these sensors, depending on the nature of the substituent on the aryl receptors, Table 2. While in all cases $\mathrm{F}^{-}$gave rise to the largest changes (almost complete quenching), in the case of $\mathbf{2}$ an approximate $70 \%$ reduction was observed upon binding with $\mathrm{H}_{2} \mathrm{PO}_{4}{ }^{-}$. Similar effects were observed in the emission spectra of $\mathbf{1}$ and $\mathbf{3}$ but the quenching was somewhat smaller, due to the less acidic receptor in $\mathbf{1}$ and the longer spacer of 3. Nevertheless, the emission spectra of $\mathbf{1}$ exhibited the greater reduction in emission upon binding with $\mathrm{H}_{2} \mathrm{PO}_{4}^{-}$in comparison to 3 .

\section{Excited state evaluation of 4 and 5 in the presence of various anions in DMSO}

The above discussion focused on the changes in the photophysical properties of 1-3. For these sensors the thiourea receptor was located at the 4-amino moiety, as it was anticipated that this would lead to more effective PET quenching of the naphthalimide excited state.

In the work of de Silva and Rice, ${ }^{16}$ when using receptors for $\mathrm{H}^{+}$, this location of the receptor was chosen due to the nature of the ICT state, and because this location alone gave rise to directional PET quenching, and hence "unidirectional, pathselective photoinduced electron transfer", ${ }^{16,30}$ that mimicked that seen in the photosynthetic reaction centre. This was investigated by Marcus and $\mathrm{Gao}^{17}$ who concluded that this directionality was "due to the difference in the electronic coupling matrix elements $(|V|)$ for the two reactions". As this directionality had not been demonstrated for anion sensing using charge neutral receptors, we consequently made $\mathbf{4}$ and $\mathbf{5}$, and investigated their anion sensing ability.

The changes in the absorption spectra of $\mathbf{4}$ upon titration with $\mathrm{AcO}^{-}$display only minor changes in the ICT band upon binding of $\mathrm{AcO}^{-}$, Fig. 2. As in the case of 2, the "structural isomer" of 4, the emission was also quenched upon titration with $\mathrm{AcO}^{-}$, Fig. 7. The changes observed at $\lambda_{\max }(528 \mathrm{~nm})$ are shown as an insert in Fig. 7, and demonstrate similar changes to those observed for $\mathbf{2}$, where quenching occurs over two log units between $4 \rightarrow 6$ and a second binding interaction takes place at higher concentrations. However, such changes occurred to a lesser extent than observed for 2, Fig. 6. These results clearly demonstrate that PET is active and that upon anion recognition of the anions the PET quenching is enhanced. In a similar manner $\mathbf{5}$ gave rise to quenching, but to a lesser extent than seen for $\mathbf{4}$ with $\mathrm{AcO}^{-}$.

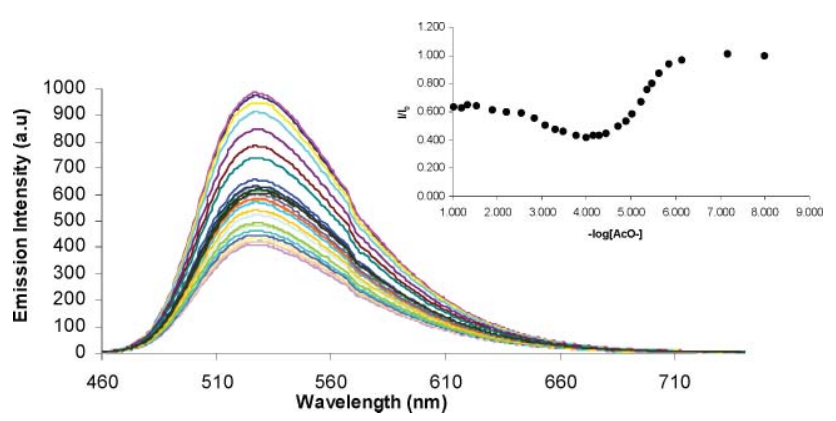

Fig. 7 Plot of intensity $v s .-\log \left[\mathrm{AcO}^{-}\right]$for titration of $\mathbf{4}$ with $\mathrm{AcO}^{-}$. Insert: the changes observed at $528 \mathrm{~nm} v s .-\log \left[\mathrm{AcO}^{-}\right]$. 
Both $\mathrm{H}_{2} \mathrm{PO}_{4}^{-}$(Fig. 8) and $\mathrm{F}^{-}$also gave rise to quenching of fluorescence in $\mathbf{4}$ and $\mathbf{5}$, where for $\mathbf{4}$ the emission was quenched by ca. 60 and $95 \%$ for $\mathrm{H}_{2} \mathrm{PO}_{4}^{-}$and $\mathrm{F}^{-}$, respectively. As seen for 1-3, the changes observed in $\mathbf{4}$ were reversed upon addition of competitive protic polar solvents such as $\mathrm{MeOH}$. Moreover, the degree of quenching is also similar in magnitude to that observed for $\mathbf{2}$ under identical conditions. In the case of $\mathbf{5}$, the changes were smaller, with the emission quenched by $c a .15$ and $30 \%$ for these ions, respectively. These results clearly demonstrate that PET is also activated in these compounds upon addition of these anions and demonstrates that bidirectional quenching is observed for such naphthalimide based anion sensors.

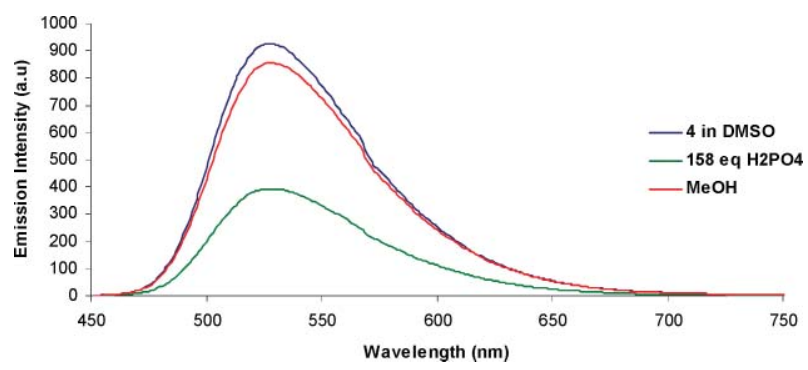

Fig. 8 The fluorescence emission spectra of 4 (top), in the presence of excess (158 eq.) $\mathrm{H}_{2} \mathrm{PO}_{4}^{-}$(bottom) and after the addition of $\mathrm{MeOH}$ (second from top).

To investigate this further, we also recorded the emission spectrum of $\mathbf{4}$ in the presence of TBAOH, which should ensure the deprotonation of the thiourea moiety and lead to strong PET quenching in a similar manner to that observed for $\mathrm{F}^{-}$. The results (see Fig. 5 ESI $\dagger$ ) showed that the emission was fully quenched upon addition of TBAOH to 4 in DMSO. This again confirms that PET was possible from the imide side.

\section{Determination of anion binding affinity}

Having demonstrated that the emission was quenched for all of the above sensors in DMSO upon addition of various anions, the binding affinity for these anion sensors was determined by fitting the above changes to various binding stoichiometries.

The results from this fitting, expressed as $\log \beta$, are summarised in Table 3. In general, for sensors 1-3 the trend in binding affinity followed the order $\mathrm{F}^{-} \geq \mathrm{AcO}^{-}>\mathrm{H}_{2} \mathrm{PO}_{4}{ }^{-}$, with $\log \beta$ of $4.4,4.0$ and 3.7, in the case of $\mathbf{2}$ for these anions, respectively. It is worth reiterating that although the $\log \beta$ value for $\mathrm{AcO}^{-}$and $\mathrm{F}^{-}$are similar, on all occasions the emission was more quenched with $\mathrm{F}^{-}$ (Table 1 and 2) and that the addition of more than one equivalent of $\mathrm{F}^{-}$leads to deprotonation.

Using the non-linear least squares regression analysis programme SPECFIT the binding affinity of $\mathbf{4}$ and $\mathbf{5}$ was also investigated. In particular, the possible formation of the $1: 1$ and the 1:2 stoichiometries were investigated. The speciation distribution diagram obtained for the binding of $\mathrm{H}_{2} \mathrm{PO}_{4}^{-}$to 4 is shown in Fig. 9, and clearly shows the formation of a single 1:1 (Guest:Host) binding (the fit is shown as an insert) with a $\log \beta$ of 3.5. This is a similar binding constant to that observed for the 'structural isomer' 2 , Table 3 .
Table 3 Binding constants for 1-5 in the presence of various anions. ${ }^{a}$

\begin{tabular}{lllll}
\hline Sensor & Anion & $\mathrm{G}: \mathrm{H}$ & $\log \beta$ & St. Dev \\
\hline $\mathbf{1}^{b}$ & $\mathrm{AcO}^{-}$ & $1: 1$ & 3.9 & - \\
& $\mathrm{H}_{2} \mathrm{PO}_{4}{ }^{-}$ & $1: 1$ & 2.9 & - \\
$\mathbf{2}^{b}$ & $\mathrm{~F}^{-}$ & $1: 1$ & 3.8 & - \\
& $\mathrm{AcO}^{-}$ & $1: 1$ & 4.0 & - \\
& $\mathrm{H}_{2} \mathrm{PO}_{4}^{-}$ & $1: 1$ & 3.7 & - \\
$\mathbf{3}^{b}$ & $\mathrm{~F}^{-}$ & $1: 1$ & 4.4 & - \\
& $\mathrm{AcO}^{-}$ & $1: 1$ & 4.5 & - \\
& $\mathrm{H}_{2} \mathrm{PO}_{4}^{-}$ & $1: 1$ & 3.1 & - \\
$\mathbf{4}^{c}$ & $\mathrm{~F}^{-}$ & $1: 1$ & 4.1 & - \\
& $\mathrm{AcO}^{-}$ & $1: 1$ & 4.2 & 0.02 \\
& & $2: 1$ & 6.2 & 0.02 \\
& $\mathrm{H}_{2} \mathrm{PO}_{4}^{-}$ & $1: 1$ & 3.5 & 0.03 \\
& $\mathrm{~F}^{-}$ & $1: 1$ & 4.7 & 0.23 \\
$\mathbf{5}^{c}$ & & $2: 1$ & 4.9 & 0.13 \\
& $\mathrm{AcO}^{-}$ & $1: 1$ & 4.2 & 0.03 \\
& & $2: 1$ & 6.2 & 0.08 \\
& $\mathrm{H}_{2} \mathrm{PO}_{4}^{-}$ & $1: 1$ & 3.2 & 0.05
\end{tabular}

${ }^{a}$ All measured in DMSO using TBA salt solutions of the corresponding anions. ${ }^{b}$ Binding constants were obtained by fitting the changes in the emission to a 1:1 binding stoichiometry using an EXCEL based non-linear regression analysis program, with an estimated error of $c a .10 \% .{ }^{c}$ Binding constants were obtained by fitting the changes in the emission using the non-linear regression analysis program SPECFIT.

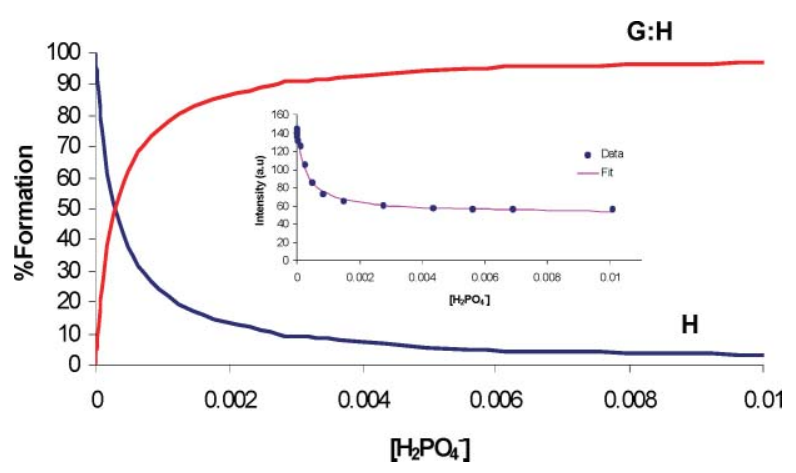

Fig. 9 Speciation distribution diagram for the binding of 4 with $\mathrm{H}_{2} \mathrm{PO}_{4}^{-}$, showing the formation of a 1:1 stoichiometry between $\mathbf{4}$ and the anion. Inset: The observed changes in the fluorescence emission and the fitting for $\lambda_{\max }$, obtained by using SPECFIT.

Similarly, fitting the data obtained for the titration of $\mathbf{4}$ with $\mathrm{AcO}^{-}$, Fig. 10, showed an initial formation of a 1:1 complex $(\log \beta=4.2)$, followed by the formation of a complex with $2: 1$ stoichiometry $(\log \beta=6.2)$ at higher concentrations, which is similar to that obtained for 2 . The overall results strongly indicate that in the case of the 1:1 binding stoichiometry, the location of the receptor does not seem to have significant effect on the sensitivity of the anion recognition. Hence, this opens up a new avenue for constructing PET anion sensors based on the design principle employed in $\mathbf{4}$ and 5. The results shown in Table 3 also demonstrated that such 'simple' diaryl based thiourea receptors can give rise to selective anion recognition. Moreover, the results further demonstrate that similar binding constants are obtained for $\mathbf{4}$ and 5, which indicates that the nature of the 4-amino substitute (e.g. primary or tertiary amine) does not affect the sensitivity of the anion recognition at the receptor site to a large extent. 


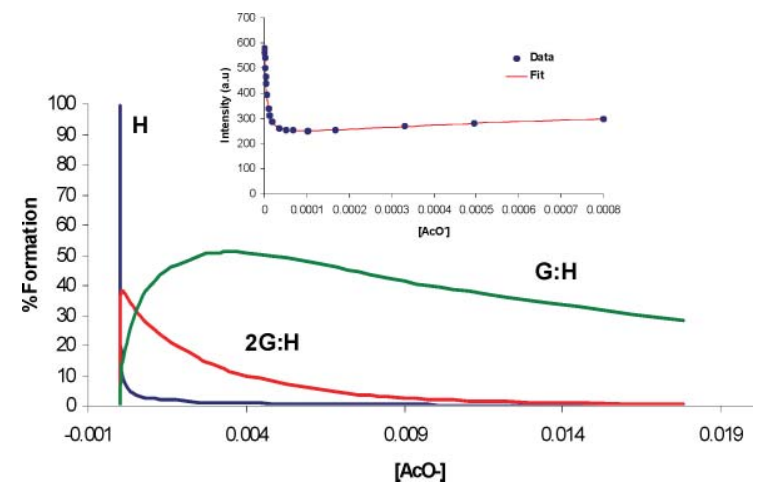

Fig. 10 Speciation distribution diagram for the binding of $\mathbf{4}$ with $\mathrm{AcO}^{-}$, showing the formation of 1:1 and 1:2 stoichiometry between 4 and the anion. Insert: The observed changes in the fluorescence emission and the fitting for $\lambda_{\max }$, obtained by using SPECFIT.

\section{Investigating bidirectional PET sensing for 6 and 9}

Having demonstrated that bidirectional PET anion sensing was possible in 'structural isomers' such as $\mathbf{2}$ and $\mathbf{4}$, we next investigated if such bidirectional PET quenching was also upheld in the $\mathrm{pH}$ PET sensors $\mathbf{6}$ and 9, (the precursors to $\mathbf{2}$ and 5, respectively). As previously mentioned, it has been demonstrated by de Silva and Rice, ${ }^{16}$ and by Marcus and Gao, ${ }^{17}$ that $\mathrm{pH}$ PET sensors possessing aliphatic amines only give rise to quenching in the fluorescence emission when the receptors are functionalised at the 4-amino moiety. We thus expected that $\mathbf{6}$ and $\mathbf{9}$ would behave similarly in aqueous solution as a function of $\mathrm{pH} .+$

The changes in the emission spectra of $\mathbf{6}$ as a function of $\mathrm{pH}$ are shown in Fig. 11 and clearly demonstrate effective 'switching on' of the naphthalimide emission upon protonation of the aniline moiety. This protonation increases the oxidation potential of the receptors, preventing PET quenching of the naphthalimide excited state. The corresponding changes in the emission of 9 are shown as an insert in Fig. 11, and demonstrate a significantly smaller emission enhancement. By plotting the changes at the $\lambda_{\max }$ for these changes as a function of $\mathrm{pH}$, a $\mathrm{pKa}$ of $c a$. 4.5 was determined for both (see Fig. 6 ESI $\dagger$ ), reflecting the acidic nature of the amine nitrogen. These results clearly demonstrate that as $\mathrm{pH}$ sensors,

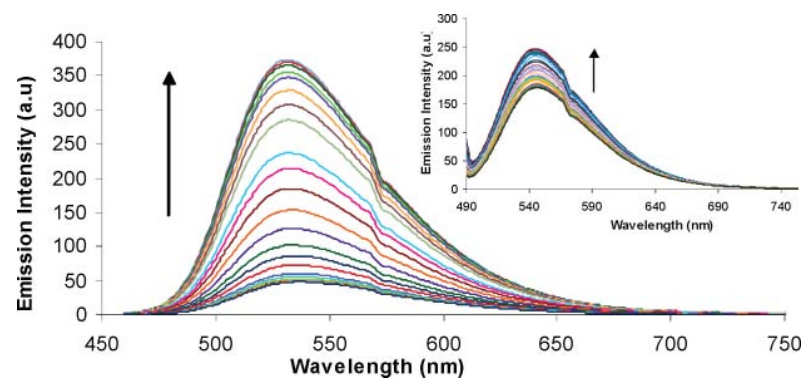

Fig. 11 The changes in the fluorescence emission spectra of 6 as a function of $\mathrm{pH}$ in $\mathrm{MeOH}: \mathrm{H}_{2} \mathrm{O}$ (50:50). Insert: the corresponding $\mathrm{pH}$ titration using 9.

\$ The pKa of the 4-amino-1,8-naphthalimide moiety in $\mathbf{6}$ is very acidic and in water is not deprotonated. Hence, no changes in the absorption spectra were expected. Similarly, 9 having a tertiary amine would also only show changes in the fluorescence emission that would correspond to the deprotonation of the aniline amine. directional PET quenching is upheld for these two 'structural isomers' in a manner proposed by de Silva and Rice. ${ }^{16}$

Having demonstrated the 'switching on' of the naphthalimide emission of 6 and 9 in water as a function of $\mathrm{pH}$, we next examined their emission in the presence and absence of $\mathrm{F}^{-}$in DMSO. However, unlike that observed for $\mathbf{2}$ and $\mathbf{4}$, no significant changes were observed in the fluorescence emission of both these precursors upon titrating with $\mathrm{F}^{-}$(see ESI $\dagger$ ). These results indicate that either: $i$ ) weak hydrogen bonding interactions, or; ii) deprotonation of the $\mathrm{N}-\mathrm{H}$ protons of these aniline moieties by $\mathrm{F}^{-}$does not result in a receptor that is sufficiently electron rich to allow for enhancement in PET quenching. Hence, the combination of: $i$ ) an electron rich receptor, and; ii) the recognition of the anion, only gives rise to PET quenching. This combination overcomes the barrier proposed by de Silva and Rice, ${ }^{16}$ and Marcus and Gao, ${ }^{17}$ enabling bidirectional PET quenching in structures such as 2 and 4.

\section{Conclusions}

Herein we have presented five PET anion sensors based on the naphthalimide structure, where in the case of 1-3 hydrogen bonding diaryl thiourea moieties were used, and connected to the 4-amino moiety of the ring. In contrast, compounds $\mathbf{4}$ and 5 had such anion receptors connected to the naphthalimide ring at the imide site. We also demonstrate that in DMSO solution ions such as $\mathrm{AcO}^{-}, \mathrm{H}_{2} \mathrm{PO}_{4}^{-}$and $\mathrm{F}^{-}$give rise to an enhancement in the PET quenching of these structures, as the $\Delta \mathrm{G}_{\mathrm{ET}}$ became more thermodynamically favourable upon binding of anions at the thiourea receptors. Hence, these results demonstrate that the emission can be quenched from either 'end' of the naphthalimide moiety; a phenomenon not normally seen for naphthalimide based sensors for cations, as we also demonstrated using compounds 6 and 9 (which are pH PET sensors), the precursors to 2 and 4, respectively. Hence, unlike other naphthalimide based sensors, based on the fluorophore-spacer-receptor model, these PET sensors give rise to bidirectional quenching upon recognition of anions, independent of the location of the receptor.

Our investigation also showed that in DMSO solution, the addition of $\mathrm{F}^{-}$to solutions of $\mathbf{6}$ or $\mathbf{9}$ did not result in quenching of their excited states, which indicates that the presence of the thiourea moiety was essential to achieve PET quenching in 1-5 in the presence of anions. Hence, compounds 1-5 are examples of naphthalimide structures where PET quenching can occur from anion receptors located either at the 4-amino moiety or at the imide site, which demonstrates the feasibility of bidirectional PET quenching in such structures upon anion recognition.

\section{Experimental}

All chemicals were obtained from Sigma-Aldrich or Fluka and unless specified, were used without further purification. Chromatographic columns were run using Silica gel 60 (230-400 mesh ASTM). Deuterated solvents for NMR use were purchased from Apollo Ltd. NMR spectra were recorded using a Bruker Advance III spectrometer, operating at $400 \mathrm{MHz}$ for ${ }^{1} \mathrm{H}-\mathrm{NMR}$ and $100 \mathrm{MHz}$ for ${ }^{13} \mathrm{C}$-NMR. NMR data were processed using Bruker Win-NMR 5.0 software. Electrospray mass spectra were recorded on a Mass Lynx NT V 3.4 on a Waters 600 controller 
connected to a 996 photodiode array detector with HPLC-grade methanol, or acetonitrile as carrier solvents. Accurate molecular weights were determined by a peak-matching method, using leucine enkephaline (H-Tyr-Gly-Gly-Phe-Leu-OH) as the standard internal reference $(\mathrm{m} / \mathrm{z}=556.2771)$; all accurate mass were calculated to $\leq 5 \mathrm{ppm}$. Melting points were determined using an Electrothermal IA9000 digital melting point apparatus. Infrared spectra were recorded on a Mattson Genesis II FTIR spectrometer equipped with a Gateway 2000 4DX2-66 workstation and on a Perkin Elmer Spectrum One FT-IR Spectrometer equipped with Universal ATR sampling accessory. Elemental analysis was carried out at the Microanalysis Laboratory, School of Chemistry and Chemical Biology, University College Dublin.

\section{Synthesis of 1}

To a solution of $6(0.250 \mathrm{~g}, 0.723 \mathrm{mmol})$ in dry chloroform $(30 \mathrm{ml})$ was added phenyl isothiocyanate $(0.108 \mathrm{~g}, 0.796 \mathrm{mmol})$ under an argon atmosphere. The resulting solution was stirred overnight at room temperature then concentrated in vacuum. The residue was extracted with chloroform and the organic phase was washed with $1 \mathrm{M} \mathrm{HCl}$, water and brine, dried over sodium sulfate, and evaporated to dryness. The product was purified by flash column chromatography on silica gel, eluting with chloroform to afford $\mathbf{1}$ $(0.191 \mathrm{~g}, 58 \%)$ as light yellow solid, $\mathrm{mp} 204-206^{\circ} \mathrm{C}$. Anal. calcd for $\mathrm{C}_{28} \mathrm{H}_{24} \mathrm{~N}_{4} \mathrm{O}_{2} \mathrm{~S} \cdot \mathrm{CH}_{2} \mathrm{Cl}_{2} . \mathrm{CHCl}_{3}: \mathrm{C}, 55.40 ; \mathrm{H}, 4.34 ; \mathrm{N}, 8.61$. Found: C, 53.89; H, 3.83; N, 8.40. ${ }^{1} \mathrm{H}-\mathrm{NMR}$ (400 MHz, DMSO-d $\left.{ }_{6}\right): 1.17$ (t, $3 \mathrm{H}, J=7.0 \mathrm{~Hz}), 4.05(\mathrm{q}, 2 \mathrm{H}, J=7.0 \mathrm{~Hz}), 4.64(\mathrm{~d}, 2 \mathrm{H}, J=5.2 \mathrm{~Hz})$, $6.71(\mathrm{~d}, 2 \mathrm{H}, J=8.5 \mathrm{~Hz}), 7.11(\mathrm{t}, 1 \mathrm{H}, J=7.5), 7.29-7.38(\mathrm{~m}, 4 \mathrm{H})$, 7.44-7.48 (m, 4H), $7.72(\mathrm{t}, 1 \mathrm{H}, J=7.5), 8.20(\mathrm{~d}, 1 \mathrm{H}, J=8.5)$, 8.43 (bs, $-\mathrm{NH}), 8.47$ (d, $1 \mathrm{H}, J=8.5 \mathrm{~Hz}), 8.78(\mathrm{~d}, 1 \mathrm{H}, J=8.5 \mathrm{~Hz})$, 9.72 (bs, -NH). ${ }^{13} \mathrm{C}-\mathrm{NMR}\left(400 \mathrm{MHz}, \mathrm{DMSO}-\mathrm{d}_{6}\right): 179.62,163.53$, $162.70,150.38,143.41,138.08,134.90,133.92,130.67,129.38$, $128.49,127.14,125.56,125.52,124.51,123.93,122.75,122.06$, $120.33,113.02,108.28,104.58,45.57,34.25,13.30$; IR $\left(\mathrm{cm}^{-1}\right)$ : 3358.25 , 2974.67, 2930.51, 2108.40, 1679.89, 1639.20, 1579.42, 1536.61, 1390.62, 1346.46, 1248.30, 1181.13, 1100.96, 1065.87, 910.04, 876.30, 773.32, 757.12, 694.44, 581.43; MS (ES) Calcd for $\left(\mathrm{M}+\mathrm{H}^{+}\right) \mathrm{m} / z$ 481.1698, Found 481.2174.

\section{Synthesis of 2}

To a solution of $6(0.250 \mathrm{~g}, 0.723 \mathrm{mmol})$ in dry chloroform $(30 \mathrm{ml})$ was added 4-(trifluoromethyl)phenyl isothiocyanate $(0.161 \mathrm{~g}$, $0.796 \mathrm{mmol}$ ) under an argon atmosphere. The resulting solution was stirred overnight at room temperature then concentrated in vacuum. The residue was extracted with chloroform and the organic phase was washed with $1 \mathrm{M} \mathrm{HCl}$, water and brine, dried over sodium sulfate, and evaporated to dryness. The residue was purified by flash column chromatography on silica gel, eluting with chloroform to afford $2(0.245 \mathrm{~g}, 60 \%)$ as light yellow solid, $\mathrm{mp} 157$ $159^{\circ} \mathrm{C}$. Anal. calcd for $\mathrm{C}_{29} \mathrm{H}_{25} \mathrm{~F}_{3} \mathrm{~N}_{4} \mathrm{O}_{3} \mathrm{~S} \cdot \mathrm{CHCl}_{3}$ : C, 53.94; H, 3.62; $\mathrm{N}, 8.39$. Found: C, 53.89; H, 3.83; N, 8.40. ${ }^{1} \mathrm{H}-\mathrm{NMR}(400 \mathrm{MHz}$, DMSO-d $_{6}$ ): 1.18 (t, $\left.3 \mathrm{H}, J=7.0 \mathrm{~Hz}\right), 4.05(\mathrm{q}, 2 \mathrm{H}, J=7.0 \mathrm{~Hz})$, $4.66(\mathrm{~d}, 2 \mathrm{H}, J=5.2 \mathrm{~Hz}), 6.72(\mathrm{~d}, 1 \mathrm{H}, J=8.5 \mathrm{~Hz}), 7.38-7.47(\mathrm{~m}$, $4 \mathrm{H}), 7.65-7.76(\mathrm{~m}, 4 \mathrm{H}), 8.29$ (d, $1 \mathrm{H}, J=8.5), 8.45$ (bs, NH), 8.47 $(\mathrm{d}, 2 \mathrm{H}, J=7.5 \mathrm{~Hz}), 8.74(\mathrm{~d}, 1 \mathrm{H}, J=8.5 \mathrm{~Hz}), 10.02(\mathrm{bd},-\mathrm{NH})$. ${ }^{13} \mathrm{C}-\mathrm{NMR}\left(400 \mathrm{MHz}, \mathrm{DMSO}-\mathrm{d}_{6}\right.$ ): 179.54, 163.51, 162.67, 150.35, $143.38,138.04,134.88,133.94,129.35,128.46,127.11,125.58$,
$125.55,124.55,123.93,123.64,122.72,122.00,120.23,108.19$, 104.55, 45.48, 34.27, 13.30; IR $\left(\mathrm{cm}^{-1}\right): 3451.78,3333.18,3243.50$, 2978.34, 1678.93, 1638.82, 1587.71, 1536.03, 1513.08, 1373.65, $1322.93,1250.81,1181.00,1156.70,1103.66,1063.36,878.42$, 847.56, 823.46, 772.93, 499.47; MS (ES) Calcd for $\left(\mathrm{M}+\mathrm{H}^{+}\right) \mathrm{m} / \mathrm{z}$ 549.16 , Found 549.38

\section{Synthesis of 3}

To a solution of $7(0.12 \mathrm{~g}, 0.33 \mathrm{mmol})$ in dry chloroform $(30 \mathrm{ml})$ was added 4-(trifluoromethyl)phenyl isothiocyanate $(0.09 \mathrm{~g}$, $0.43 \mathrm{mmol}$ ) and the reaction stirred for $18 \mathrm{~h}$. The resulting solution was then washed with $0.5 \mathrm{M} \mathrm{HCl}$ and water and the organic layer was dried over $\mathrm{MgSO}_{4}$, filtered and evaporated to dryness. Purification by flash column chromatography on neutral silica (chloroform) yielded $\mathbf{3}$ as a bright yellow solid $(0.09 \mathrm{~g}, 49 \%), \mathrm{mp} 182-184{ }^{\circ} \mathrm{C}$. Found: $\mathrm{C} 62.34, \mathrm{H} 4.23, \mathrm{~N}$ 9.81\%. $\mathrm{C}_{30} \mathrm{H}_{25} \mathrm{~F}_{3} \mathrm{~N}_{4} \mathrm{O}_{2} \mathrm{~S} \cdot \mathrm{H}_{2} \mathrm{O}$ requires: $\mathrm{C} 62.06, \mathrm{H} 4.69, \mathrm{~N} 9.65 \%$. $\delta_{\mathrm{H}}\left(400 \mathrm{MHz}, \mathrm{CDCl}_{3}\right): 1.33\left(3 \mathrm{H}, \mathrm{t}, J=7.0 \mathrm{~Hz}, \mathrm{CH}_{3}\right), 3.15(2 \mathrm{H}$, $\left.\mathrm{t}, J=6.5 \mathrm{~Hz}, \mathrm{NHCH}_{2} \mathrm{CH}_{2}\right), 3.74\left(2 \mathrm{H}, \mathrm{br} \mathrm{m}, \mathrm{NHCH}_{2}\right), 4.24(2 \mathrm{H}$, q, $\left.J=7.0 \mathrm{~Hz}, \mathrm{CH}_{2} \mathrm{CH}_{3}\right), 5.26\left(1 \mathrm{H}, \mathrm{br}, \mathrm{NHCH}_{2}\right), 6.79(1 \mathrm{H}, \mathrm{d}, J=$ $8.0 \mathrm{~Hz}, \mathrm{Ar}-\mathrm{H}), 7.37$ (4H, m, Ar-H), 7.58-7.67 (5H, m, Ar-H), 7.85 $(1 \mathrm{H}, 7.85(1 \mathrm{H}, \mathrm{br}, \mathrm{NH}), 7.93(1 \mathrm{H}, \mathrm{br}, \mathrm{NH}), 7.96(1 \mathrm{H}, \mathrm{d}, J=8.5 \mathrm{~Hz}$, Ar-H), $8.49(1 \mathrm{H}, \mathrm{d}, J=8.5 \mathrm{~Hz}, \mathrm{Ar}-\mathrm{H}), 8.59(1 \mathrm{H}, \mathrm{d}, J=7.5 \mathrm{~Hz}$, Ar-H); $\delta_{\mathrm{C}}\left(100 \mathrm{MHz}, \mathrm{CDCl}_{3}\right): 12.9,34.0,34.7,43.9,104.0,110.7$, $119.9,122.0,122.9,123.7,124.5,125.0,125.3,126.0,129.1,129.3$, 129.7, 130.6, 133.7, 135.0, 137.4, 140.3, 148.3, 163.4, 163.9, 179.5; $\mathrm{m} / \mathrm{z} 563(\mathrm{M}+\mathrm{H})^{+} ; v_{\max } / \mathrm{cm}^{-1} 3467,3382,3341,3231,2978,2931$, $1691,1637,1575,1545,1515,1432,1395,1369,1345,1329,1247$. 1165, 1103, 1065, 1014, 840, 770, 756.

\section{Acknowledgements}

The authors would like to thank Deakin University for financial support to FMP in the form of an overseas study programme to visit Trinity College Dublin to finalise this work, and travelling support for TG. We also thank IRCSET for a BASIC research grant awarded to PEK and TG for this project. PEK is also thankful for generous support from the Department of Chemistry, University of Canterbury.

\section{Notes and references}

1 J. L. Sessler, P. A. Gale, and W. S. Cho, Anion Receptor Chemistry, Royal Society of Chemistry, Cambridge UK. 2006; P. A. Gale, S. E. GarciaGarrido and J. Garric, Chem. Soc. Rev., 2008, 37, 151; P. Padros and R. Quesada, Supramol. Chem., 2008, 20, 201; P. A. Gale and R. Quesada, Coord. Chem. Rev., 2006, 250, 3219; M. H. Filby and J. W. Steed, Coord. Chem. Rev., 2006, 250, 3200; E. A. Katayev, Y. A. Ustynyuk and J. L. Sessler, Coord. Chem. Rev., 2006, 250, 2952; A. Gale, Acc. Chem. Res., 2006, 39, 465; J. W. Steed, Chem. Commun., 2006, 2637; J. P. Leonard and T. Gunnlaugsson, J. Fluoresc., 2005, 15, 585; R. Martínez-Máñez and F. Sancenón, Chem. Rev., 2003, 103, 4419.

2 T. Gunnlaugsson, M. Glynn, G. M. Tocci (née Hussey), P. E. Kruger and F. M. Pfeffer, Coord. Chem. Rev., 2006, 250, 3094; T. Gunnlaugsson, H. D. P. Ali, M. Glynn, P. E. Kruger, G. M. Hussey, F. M. Pfeffer, C. M. G. dos Santos and J. Tierney, J. Fluoresc., 2005, 15, 287.

3 C. M. G. dos Santos, T. McCabe, G. W. Watson, P. E. Kruger and Thorfinnur Gunnlaugsson, J. Org. Chem., 2008, 73, 9235; M. Duke, J. E. O'Brien, T. McCabe and T. Gunnlaugsson, Org. Biomol. Chem., 2008, 6, 4089; E. Quinlan, S. E. Matthews and T. Gunnlaugsson, J. Org. Chem., 2007, 72, 7497; F. M. Pfeffer, P. E. Kruger and T. Gunnlaugsson, Org. Biomol. Chem., 2007, 5, 1894; E. Quinlan, S. E. Matthews and T. Gunnlaugsson, Tetrahedron Lett., 2006, 47, 9333; F. Y. Wu, Z. Li, L. 
Guo, X. Wang, M. H. Lin, Y. F. Zhao and Y. B. Jiang, Org. Biomol. Chem., 2006, 4, 624; L. Nie, Z. Li, J. Han, X. Zhang, R. Yang, W. X. Liu, F. Y. Wu, J. W. Xie, Y. F. Zhao and Y. B. Jiang, J. Org. Chem., 2004, 69, 6449; F. M. Pfeffer, T. Gunnlaugsson, P. Jensen and P. E. Kruger, Org. lett., 2005, 7, 5357; H. D. P. Ali, P. E. Kruger and T. Gunnlaugsson, New J. Chem., 2008, 32, 1153; C. R. Cooper, N. Spencer and T. D. James, Chem. Commun., 1998, 1365.

4 C. M. G. Dos Santos, T. McCabe and T. Gunnlaugsson, Tetrahedron Lett., 2007, 48, 3135; R. M. Duke and T. Gunnlaugsson, Tetrahedron Lett., 2007, 48, 8043.

5 A. J. Lowe and F. M. Pfeffer, Chem. Commun., 2008, 1871; A. J. Lowe, G. A. Dyson and F. M. Pfeffer, Eur. J. Org. Chem., 2008, 5, 1559; A. J. Lowe, F. A. Dyson and F. M. Pfeffer, Org. Biomol. Chem., 2007, 5, 1343; F. M. Pfeffer, K. F. Lim and K. J. Sedgwick, Org. Biomol. Chem., 2007, 5, 1795.

6 M. H. Filby, S. J. Dickson, N. Zaccheroni, L. Prodi, S. Bonacchi, M. Montalti, M. J. Paterson, T. D. Humphries, C. Chiorboli and J. M. Steed, J. Am. Chem. Soc., 2008, 130, 4105; G. Y. Qing, H. J. Qin, Y. B. He, C. G. Hu, F. Wang and L. Hu, Supramol. Chem., 2008, 20, 265; J. F. Callan, R. C. Mulrooney, S. Kamila and B. McCaughan, J. Fluoresc., 2008, 18, 527; Y. K. Kim, H. N. Lee, N. J. Singh, H. J. Choi, J. Y. Xue, K. S. Kim, J. Yoon and M. H. Hyun, J. Org. Chem., 2008, 73, 701; M. K. Choi, H. N. Kim, H. J. Choi, J. Yoon and M. H. Hyun, Tetrahedron Lett., 2008, 49, 4522; S. Y. Liu, Y. B. He, W. H. Chan and A. W. M. Lee, Tetrahedron, 2006, 62, 11687; R. Nishiyabu and P. Anzenbacher Jr., J. Am. Chem. Soc., 2005, 127, 8270; H. Miyaji, H.-K. Kim, E.-K. Sim, C.-K. Lee, W.-S. Cho, J. L. Sessler and C.-H. Lee, J. Am. Chem. Soc., 2005, 127, 12510-12512; J. Singh, S. J. Kim, H. G. Kim, J. K. Kim, L. W. Lee, K. S. Kim and J. A. Yoon, Org. Lett., 2003, 54, 2083; S. Goetz and P. E. Kruger, Dalton Trans., 2006, 1277.

7 W. Dehaen, P. A. Gale, S. E. García-Garrido, M. Kostermans and M. E. Light, New J. Chem., 2007, 31, 691; R. Nishiyabu, M. A. Palacios, W. Dehaen and P. Anzenbacher, J. Am. Chem. Soc., 2006, 128, 11496; D. R. Turner, M. J. Paterson and J. W. Steed, J. Org. Chem., 2006, 71, 1598; I. Rozas and P. E. Kruger, J. Chem. Theory Comput., 2005, 1, 1055 .

8 H. J. Kim, S. K. Kim, J. Y. Lee and J. S. Kim, J. Org. Chem., 2006, 71, 6611; R. Nishiyabu and P. Anzenbacher, Org. Lett., 2006, 8, 359; Y. Li, L. F. Cao and H. Tian, J. Org. Chem., 2006, 71, 8279.

9 T. Gunnlaugsson, A. P. Davis, J. E. O'Brien and M. Glynn, Org. Lett., 2002, 4, 2449; T. Gunnlaugsson, A. P. Davis and M. Glynn, Chem. Commun., 2001, 2556.

10 C. M. G. dos Santos, M. Glynn, T. McCabe, J. S. Seixas de Melo, H. D. Burrows and T. Gunnlaugsson, Supramol. Chem., 2008, 20, 407.

11 A. P. de Silva, H. Q. N. Gunaratne and T. Gunnlaugsson, Tetrahedron Lett., 1998, 39, 5077; A. P. de Silva, H. Q. N. Gunaratne, T. Gunnlaugsson and M. Nieuwenhuyzen, Chem. Commun., 1996, 1967.
12 T. Gunnlaugsson, A. P. Davis, J. E. O’Brien and M. Glynn, Org. Biomol. Chem., 2005, 3, 48; T. Gunnlaugsson, A. P. Davis, G. M. Hussey, J. Tierney and M. Glynn, Org. Biomol. Chem., 2004, 2, 1856.

13 S. Xu, K. C. Chen and H. Tian, J. Mater. Chem., 2005, 15, 2676; Y. Sun, C. Zhong, R. Gong and E. Fu, Org. Biomol. Chem., 2008, 6, 3044; X.-P. Bao, L. Wang, L. Wu and Z.-Y. Li, Supramol. Chem., 2008, 20, 467.

14 H. He, M. A. Mortellaro, M. J. P. Leiner, R. J. Fraatz and J. K. Tusa, J. Am. Chem. Soc., 2003, 125, 1468.

15 A. P. de Silva, H. Q. N. Gunaratne, T. Gunnlaugsson, A. J. M. Huxley, C. P. McCoy, J. T. Rademacher and T. E. Rice, Chem. Rev., 1997, 97, 1515.

16 A. P. de Silva and T. E. Rice, Chem. Commun., 1996, 163.

17 Y. Q. Gao and R. A. Marcus, J. Phys. Chem. A, 2002, 106, 1956.

18 Y. Xiao, M. Fu, Z. Qian and J. Cui, Tetrahedron Lett., 2005, 46, 6289.

19 H. Tian, T. Xu, Y. Zhao and K. Chen, J. Chem. Soc., Perkin Trans. 2, $1999,545$.

20 T. Gunnlaugsson, C. P. McCoy, R. J. Morrow, C. Phelan and F. Stomeo, Arkivoc, 2003, 8, 216.

21 R. Parkesh, T. C. Lee and T. Gunnlaugsson, Org. Biomol. Chem., 2007, 5, 310; T. Gunnlaugsson, T. C. Lee and R. Parkesh, Org. Biomol. Chem., 2003, 1, 3265.

22 H. D. P. Ali, P. E. Kruger and T. Gunnlaugsson, New J. Chem., 2008, 32, 1153.

23 T. Gunnlaugsson, P. E. Kruger, P. Jensen, J. Tierney, H. D. P. Ali and G. M. Hussey, J. Org. Chem., 2005, 70, 10875.

24 G. J. Ryan, S. Quinn and T. Gunnlaugsson, Inorg. Chem., 2008, 47, 401.

25 Part of this work has been previously communicated: T. Gunnlaugsson, P. E. Kruger, T. C. Lee, R. Parkesh, F. M. Pfeffer and G. M. Hussey, Tetrahedron Lett., 2003, 44, 6575.

26 Part of this work has been previously communicated: E. B. Veale and T. Gunnlaugsson, J. Org. Chem., 2008, 73, 8073.

27 R. A. Bissell, A. P. de Silva, H. Q. N. Gunaratne, P. L. M. Lynch, G. E. M. Maguire, C. P. McCoy and K. R. A. S. Sandanayake, Top. Curr. Chem., 1998, 168, 223; R. A. Bissell, A. P. de Silva, H. Q. N. Gunaratne, P. L. M. Lynch, G. E. M. Maguire and K. R. A. S. Sandanayake, Chem. Soc. Rev., 1992, 21, 187.

28 T. Gunnlaugsson, P. E. Kruger, P. Jensen, F. M. Pfeffer and G. M. Hussey, Tetrahedron Lett., 2003, 44, 8909; S. Camiolo, P. A. Gale, M. B. Hursthouse and M. E. Light, Org. Biomol. Chem., 2003, 1, 741; D. E. Gómez, L. Fabbrizzi, M. Licchelli and E. Monzani, Org. Biomol. Chem., 2005, 3, 1495.

29 F. M. Pfeffer, M. Seter, N. Lewcenko and N. W. Barnett, Tetrahedron Lett., 2006, 47, 5251.

30 A. P. de Silva, A. Goligher, H. Q. N. Gunaratne and T. E. Rice, Arkivoc, 2003, 7, 229. 